\title{
CAHLE MEDIEVALE DESCOPERITE ÎN MUNTENIA DECORATE CU SCENA LEUL BĂRBOS PAZIND COPACUL VIETII
}

Maria Venera Rădulescu

\section{MEDIEVAL STOVE TILES DISCOVERED IN MUNTENIA COUNTY FEATURING THE BEARDED LION GUARDING THE TREE OF LIFE}

The rich omamental pattem of medieval stove tiles found in Romania includes the bearded lion guarding the tree of life theme from a popular story of that time in Europe. This particular theme is found on terracotta tiles from the $\mathrm{XV}^{\mathrm{Ul}}$ century discovered in Central Europe. In Romania, tiles decorated with this theme and dating from the end of $\mathrm{XV}^{\mathrm{th}}$ century were found at Suceava Stronghold, Vaslui Royal Court, Făgăraş Stronghold and Târgovişte Royal Court.

This omamental theme is found also on stove tiles dating from the end of the $X V I^{\text {th }}$ century, that were discovered at the I'loci City (today in ruins), at that time located where lalomiţa and Danube rivers merge, at the border between Muntenia County and the Ottoman Empire. The archaeological excavations from 1978, 1980, 1995-1996 uncovered several fragments and a whole piece that were components of heating stoves from two dwellings dating from the end of the XVI ${ }^{\text {th }}$ century to the beginning of the XVII ${ }^{\text {th }}$ century.

This paper analyses the iconography of these artifacts. At the Floci City, the theme was adapted to the local medieval mentality. In that respect, the lion is guarding a tree of life with branches represented by small crosses. Thus, the whole theme is enriched with the symbol of holding intact the Christian religion, paramount for the survival of a small Christian nation geographically located in the close proximity of a powerful Middle Age Muslim Empire.

Key words: stove tiles, bearded lion, stronghold, divelling, tree of life, little crosses.

Cuvinte cheie: cahle, leu bărbos, cetate, locuinţă, copacul vieţii, cruciuliţe.

Ornamentica variată a cahlelor medievale descoperite pe teritoriul României înscrie şi compoziţia Leul bărbos păzind copacul vietii, ilustrarc a unui episod dintr-o frumoasă poveste ce circula în epocă pe continent.

În Europa centrală teracote ornate cu accastã scenă, des baumbewachenden Löwen, sunt cunoscute încă din prima jumătate a secolului al XV-lea. Cea mai timpurie este o piesă de coronament, datată 1435, ce provine de la Basel şi este atribuită meşterului olar Peter Hartlieb'. Cahle de coronament cu acelaşi subiect au fost folosite la jumătatea aceluiaşi secol pentru decorarea unor sobe de la Ravensburg ${ }^{2}$. Soba cu cavaleri, ,der Ritterofen", construitā în a doua jumătate a secolului al XV-lea, din ordinul lui Ladislau al Vlea Postumul, la Palatul Regal de la Buda, cuprindea şi teracote decorate cu acest subiect ${ }^{3}$ (Pl.

\footnotetext{
'Franz 1969. 50, Abb. 94.

2 Firanz 1969. Abb. 93. Soba se află astăzi expusă la lictoria and Albert Museum, Londra; o altă sobă la Ravensburg. vezi lloll 1958. lig. 105.

${ }^{3}$ Holl 1958. 258. fig. 72. fig. 110 - harla descoperirilor; Voit, IHoll 1963. pl. II (soba reconstructie grafică), pl. VIII (fig. din centru).
}

1/4). Un fragment de teracotă de la sfârșitul secolului al XV-lea pe care se poate observa barba bogată, cârlionţată, precum şi labele anterioare ale leului culcat, orientat spre stânga, a fost descoperit şi în Celiia, la Tvrz u Chocnět.

În România, pentru teritoriul Moldovei, literatura de specialitate a semnalat până în prezent un mic fragment de cahlă, acoperit cu angobă albă, pe care este redat capul unui leu cu trăsături omeneşti, încadrat de o barbă cârliontată şi o coamă bogată, provenind de la Cetatea de la Suceava ${ }^{5}$. Piesa datează de la sfârşitul secolului al XV-lea (Pl. 1/1).

Două piese au fost descoperite în anul 1990 în preajma Curţii Domneşti de la Vasluí. Teracotele, de formă dreptunghiulară $(26,5 \times 22,5$ $\mathrm{cm}$ ), cu o grosime a plăcii de $1,5 \mathrm{~cm}$, păstrează pe

\footnotetext{
${ }^{4}$ Richterova 1982, 57. nr. 34, tab. 8:2.

${ }^{5}$ Batariuc 1995, 115, fig. 3:1; Batariuc 1999, 110-111, fig. 36:1.

${ }^{6}$ Piesele, inedite, se află în colecţia Muzeului Judeţean .Stefan cel Mare” de la Vaslui. Multumim conducerii muzeului şi colegilor muzeografi care ne-au pus la dispoziţie ilustraţia şi ne-au permis publicarea piesei.
} 
revers, parłial, sistemul de fixare pe peretele sobei ${ }^{7}$, precum şi urme de funingine din timpul folosirii instalaţiei de încălzit. La confecţionare a fost folosită o pastă de lut omogenă, în compoziţie cu nisip fin. Imprimarea motivului decorativ s-a făcut cu ajutorul unui tipar, pe revers observându-se amprentele degetelor meşterului, din timpul presării lutului în matriţă. Coacerea ceramicii a fost completă. Teracotele nu sunt smălţuite, iar aversul are un aspect aspru, probabil de la nisipul pus în tipar cu scopul de a uşura desprinderea piesei. Tiparul a fost uşor tocit.

Teracotele au marginile uşor înălţate, în fonnă de ramă. Scena este încadrată de un chenar simplu, compus din câte două nervuri paralele ce urmăresc forma plăcii, formând două dreptunghiuri circurnscrise. În câmp, culcat, orientat spre stânga, este figurat leul bărbos, păzind copacul vieţii. Animalul, cu figură umană şi barbă lungă, stufoasă, cste încadrat de câte un copac, cu frunziş (Pl. 1/2). Locul descoperirii, rezolvarea stilistică a imaginii, precum şi materialul şi tehnica de execuţie pledează pentru atribuirea acestor piese Curţii Domnești de la Vaslui, din timpul lui Ştefan cel Mare (1457--1504).

Motivul decorativ se întâlneşte şi la sobele medievale din Transilvania.

La Cetatea Făgăraș, în nivelul datat în a doua jumătate a secolului al XV-lea, a fost găsită o placă ceramică în formă de scut, pe care este figurat un leu cu barbă lungă, culcat spre stânga, pe o terasă, susţinând cu labele anterioare trunchiul unui arbore. Piesa este acoperită cu alb, mat ${ }^{8}$.

Tot la Cetatea Făgăraş, într-o groapă de mari dimensiuni, practicată şi umplută anterior transformărilor suferite de incinta cetăţii centrale de zid în prima parte a secolului al XVI-lea, au fost descoperite mai multe fragmente ceramice ce au făcut posibilă reconstituirea grafică a unei cahleplacă dreptunghiulară $(24,4 \times 19,7 \times 1,2 \mathrm{~cm})$ ce are ca decor un leu cu figură umană, încadrată de o barbă lungă, cârlionţată, culcat, orientat spre stânga. Coada, trecută printre picioarele posterioare, se sprijină pe sol, sub abdomenul său. Leul susţine cu labele anterioare un arbore, iar în

\footnotetext{
${ }^{7}$ Pentru sistemul de lixare a cahlelor pe peretele sobei, vezi Popa, Mărgineanu-Cârstoiu 1979, passint.

${ }^{8}$ Ilicscu, Puşcaşu 1970, 14. nr. 11, fig. 16.
}

spatele animalului este redat un al doilea arbore. Compoziţia este încadrată de un chenar decorat cu flori de crin, dublat pe lăţime, pe ambele laturi, de câte o friză cu decor stelat (Pl. 2/1). Grafia leului şi a arborelui vieţii își găsește analogie la teracota ce provine de la Palatul Regal de la Buda', cu observaţia că la piesa descoperită la Cetatea Făgăraş chenarul este modificat.

Placa poate fi datată între sfârşitul secolului al XV-lea şi primii ani ai secolului următor. Piesele de la Făgăraş din această grupă nu sunt smălţuite; unele au aversul netratat, iar la altele el este acoperit cu un strat subțire de angobă albă $^{10}$.

Câteva fragmente ceramice descoperite la Cetatea Făgăraş provin de la teracote ce înscriu o variantă a compoziţiei enunţate mai sus. Unul dintre acestea, din partea inferioară a cahlei ${ }^{1 l}$ ( 1 . totală: $25,5 \mathrm{~cm}$, L. păstrată: $19,1 \mathrm{~cm}$ ), are ca decor leul culcat, de astă dată orientat spre dreapta. Coada animalului trece printre picioarele posterioare şi se ridică deasupra crupei, unde se bifurcă (Pl. 2/2); frunzişul copacilor şi decorul chenarului sunt redate diferit faţă de piesa deja descrisă. Pe alte fragmente, din partea superioară a unor piese ceva mai mici (l. totală: $20 \mathrm{~cm}$ ), se observă doar frunzişul copacilor ${ }^{12}(\mathrm{Pl} .2 / 3)$. Piesele sunt smălţuite în verde, irizat spre argintiu ${ }^{13}$. Tiparul folosit la imprimarea decorului acestor cahle a fost creat, probabil, de meşterii locali.

Sobele medievale de pe teritoriul Munteniei au abordat la rândul lor omamentul enunţat dar teracotele nu au fost până acum publicate.

De la Curtea Domnească din Târgovişte provine o frumoasă cahlă dreptunghiulară, smălţuită în verde intens (L. totală: $26,5 \mathrm{~cm}, 1$. păstrată: $22 \mathrm{~cm}$ ). Din păcate, din corpul de fixare pe peretele sobei nu au mai rămas pe reversul piesei decât foarte mici fragmente ${ }^{14}$.

\footnotetext{
9 Pentru alte analogii, vezi Tamási 1995, 31-35, apud Marcu-Istrate 2004, 96; Puşcaşu 1980, 270, nota 4 analogie cu piesa descoperitả la Egger (Ungaria).

${ }^{10}$ Puşcaşu 1980, 232, fig. 9.

"Marcu-Istrate 2004, Pl. 63:62.

${ }^{12}$ Marcu-Istrate 2004, PI. 63:62.

${ }^{13}$ Marcu-Istrate 2004. 219-220, nr. 62-63.

14 Piesa a lost găsită în anul 1968: în prezent se află în colectiia arh. Cornel lonescu (nr. inv. 0846). Multumim
} 
Teracota a fost confecţionată din pastă de lut omogenă, în compoziţie cu nisip fin şi rare paiete de mică. Decorul a fost imprimat cu ajutorul unui tipar. Smalţul a înecat pe alocuri modelul. Coacerea ceramicii este completă.

Compoziłia este încadrată într-un chenar stilizat sugerând un şnur. În câmpul cahlei, centrat, cste figurat un leu şezând, orientat spre dreapta, privind frontal. Leul are o barbă lungă, stufoasă. Coada leului trece printre picioarele posterioare, se ridică deasupra crupei unde se bifurcă. $\mathrm{Cu}$ labele anterioare susţine trunchiul unui copac cu frunziş bogat, al doilea copac fiind redat în spatele animalului (Pl. 3). Compoziţia are reale calităţi artistice, creatorul tiparului fiind, desigur, un bun desenator şi executor al modelajului. De amintit că la Târgovişte au mai fost descoperite două Iragmente cu decorul amintit, un fragment ce provine de la o piesă nesmălyuită, iar celălalt de la o piesă acoperită cu angobă albă ${ }^{15}$.

Referitor la stabilirea cronologiei piesei avem în vedere analogia cu cahlele descoperite la Cetatca Făgăraş (varianta) ${ }^{16}$. Grafia desenului este identică, dimensiunile sigur păstrate înscriu aceleaşi coordonate, respectiv la Făgăraş $25,5 \mathrm{~cm}$ pentru lăţime, iar la Târgovişte $26,5 \mathrm{~cm}$ pentru lungime, ccea ce poate reconstitui o teracotă de formă aproximativ pătrată. $O$ altă analogie este aplicarea smaltului verde, pe aversul pieselor. $O$ diferență apare doar la motivul decorativ al chenarului. Toate aceste indicii ne justifică ipoteza că teracotele amintite, omate în aceeaşi manieră, au fosl confectionate în acelaşi atelier.

Provenienţa teracotei de la Palatul Domnesc din Târgovişte, arie în care a fost descoperită şi o piesã decorată cu motive inspirate din arhitectura gotică, smălquită verde oliv ${ }^{17}$, ambelc decoruri cu analogii la soba din Palatul Regal de la Buda (Ofen mit den Ritterfiguren), ne indică existenţa în Palatul voievozilor munteni, la finele secolului al XV-lea şi în primii ani ai sccolului următor, a unci instalaţii de încălzit inspirată de soba sau sobele din Ungaria.

coleçionarului, şi pe aceastã cale. pentru amabilitatea de a ne permite cercetarca şi publicarea teracotei.

15. Informaţii arh. Cornel lonescu.

16 Vexi supra nota 12.

${ }^{17}$ Rădulescu 2000. 94-96, fïg. 2.
Cercetările arheologice din anii 1978 şi 1980 de la Oraşul de Floci ale ruinelor unei locuinte medievale de la sfârşitul secolului al XVIlea - începutul secolului al XVII-lea, locuinţă dotată cu o instalaţie de încălzit de tipul sobei de cahle, au scos la lumină printre teracotele decorate cu oşteni ecveştri ${ }^{18}$ şi câteva fragmente provenind de la o cahlă decorată cu scena leul bărbos păzind copacul viefii ${ }^{19}$.

S-a folosit o pastă de lut omogenă, decorul fiind imprimat cu un tipar. După uscare şi prima coacere, aversul plăcii a fost angobat, s-a aplicat o vopsea de culoare verde, folosindu-se oxidul de cupru, iar apoi smalţul. A urmat cea de a doua coacere în cuptor, completă.

Fragmentele descoperite aparţin unei teracote rectangulare, lăţimea fiind de $24 \mathrm{~cm}$. Bordurile sunt uşor înălţate şi lăţite, în formă de ramă. Perimetral, este creat un chenar dinti de fierăstrău, cu vârful spre interior. Pe fragmente se observă, ca decor, capul leului cu barbă stufoasă, redat frontal, iar în dreapta sa copacul vieţii (colţul din stânga, sus), coada bifurcată a leului (colţul din dreapta, sus) şi în registrul inferior elemente de peisaj (Pl. 4/1).

Pe revers se păstrează urme de funingine şi arsură, survenite în timpul folosirii instalaţiei de încălzit dar şi în urma incendierii locuinţei.

Cercetarea arheologică din anii 1994 şi 1995 a unei alte locuinţe medievale de la Oraşul de Floci, L $5 \mathrm{~A}^{20}$ (PI. 5/1), a scos la lumină un bogat lot de cahle-borcan precum şi trei cahle-placă, două decorate cu imaginea oştean ecvestru, spre dreapta, iar cea de a treia ornamentată cu scena leul bărbos păzind copacul vietii ${ }^{21}$. Teracota are dimensiunile de $25,5 \times 24 \mathrm{~cm}$. Pe reversul plăcii este ataşată, perimetral şi perpendicular pe margini, o bandă ceraınică lată de $5,3 \mathrm{~cm}$, utilă în procesul

\footnotetext{
${ }^{18}$ Investigatiile (S XIX, S XIX a, SXIX b) au fost efectuate în curtea fostei .I.A.S. Avicola”. Giurgeni. Vezi Rădulescu. în Chił̧escu el alii 1981. 132-139: Rădulescu, în Chilescu et alii 1982. 140-147.

19 Fragmentele ceramice se afla în colecplia MNIR, nr. inv. $163779,163799,163800,163801.163805$.

${ }^{20}$ Chițescu. Teodor 1996, 89. nr. 107: Chiţescu. Teodor 1997. 44-45, nr. 78: Teodor 1998, 48-49, nr. 56

21 Mulųumim şi pe această cale arheologului dr. Eugen Silviu Teodor, autorul descoperirii. care nc-a permis studierea şi publicarea piesci. Piesa se află în colceția Muzcului Naţional de Istorie a României, fărā nr. inv.
} 
de prindere a cahlei, cu lut, pe peretele instalaţiei de incălzit. Piesa a fost lucrată din pastă de lut, în compoziţie cu nisip fin. Motivul decorativ, în relief, a fost imprimat cu ajutorul unui tipar. Pe revers se observă amprenta mâinii meşterului, din momentul presării lutului în matriţă. Smalţul, de culoare verde, a fost mult degradat, exfoliat, ars, atacat de compuşii chimici din sol, în prezent păstrându-se doar parţial, în colţul din stânga sus şi pe latura dreaptă a piesei.

Cahla a fost găsită întreagă, fapt ce a permis reconstituirea imaginii piesei descoperită, doar sub forma câtorva fragmente, în locuinta cercetată în anul 1978 şi prezentată mai sus. Tiparul pieselor descoperite în cele două locuinte a fost acelaşi, ceea ce indică provenienţa lor din acelaşi atelier, existent în mod cert la Oraşul de Floci, cunoscut centru ceramic medieval.

Bordurile teracotei sunt uşor înălţate şi lătite $(1 \mathrm{~cm})$, în fonnă de ramă. Scena este încadrată într-un chenar dinfi de fierăstrău, cu vârful spre interior. În câmpul piesei, centrată, este redată imaginea unui leu, şezând, orientat spre stânga, privind frontal. Animalul, cu figură umană, are urechile ascutite, o barbă lungă, stufoasă, coada trecută printre picioarele posterioare, înălţată deasupra crupei, unde se bifurcă. Pe laba sa anterioară dreaptă se sprịină copacul vieţii. În registrul inferior sunt introduse elementele de peisaj, patru copăcei, alternând cei din categoria foioase cu brăduţii (Pl. 4/2, Pl. 5/2). Punerea în pagină este armonioasă, echilibrată.

Atragem atenţia asupra rezolvării plastice a copacului vietii, diferit de ceilalţi arbori, redat doar prin crenguțe ce se întretaie formând mai multe cruciuliţe, simbol cu evident conţinut creștin, ceea ce dă un nou înțeles, metaforic, întregii compoziţii.

Pentru stabilirea cronologiei teracotelor descoperite la Oraşul Floci, decorate cu acest subiect, avem în vedere stratigrafia sectiunilor arheologice efectuatc în timpul cercetării celor două locuințe medievale, tipologia formei pieselor şi asocierea lor, în cadrul instalaţiilor de încălzit, cu tcracotele ornate cu oşteni ecveştri. Toate acestea indică sfârşitu! secolului al XVI-lea, probabil cu o perioadă de funcţionalitate a sobelor până la începutul secolului următor.
Instalaţiile de încălzit de la Oraşul Floci ornate atât cu oşteni ecveştri cât şi cu scena leul bărbos păzind copacul vietiii capătă, în context, o importanţă specială prin redarea sugestivă a temelor iconografice.

Perpetuarea motivului decorativ folosit la sfârşitul secolului al XV-lea - primii ani ai secolului al XVI-lea la teracotele, până la sfârşitului acestui secol, la sobele unor locuinţe din oraşul aflat la vărsarea Ialomiţei în Dunăre, îşi poate găsi explicaţia în funcţionarea încă a unora dintre mai vechile instalaţii de încălzit, fapt ce a permis copierea decorului, adaptat inteligent realităţilor locale.

$\mathrm{Nu}$ putem vorbi, în cazul de faţă, de aducerea tiparelor sau a mărfii din altă parte pentru simplul motiv că redarea grafică a compoziţiei are elemente particulare, elemente ce tin de fantezia meşterilor locali ialomiţeni, înzestraţi cu reale abilităţi artistice. Redarea compoziţiei în maniera descrisă este proprie doar teracotelor de la Oraşul de Floci.

Se poate înţelege însă mai mult decât preluarea şi perpetuarea unui motiv decorativ. Depăşind caracterul de episod al unei frumoase povestiri medievale, ne putem gândi la înţelesul metaforic al imaginii. Leul, ca emblemă a puterii suverane, a puterii nobile, apare frecvent în heraldică. Compoziţia cahlelor de la Oraşul de Floci atribuie acestui simbol animalier al autorităţii atributele de apărător al credinței creștine. Tema iconografică este în strânsă legătură cu momentul istoric al naşterii creaţiei de artă plastică la care ne referim, iar amplasarea geografică a Oraşului de Floci, în imediata vecinătate a Imperiului Otoman, a stimulat la rândul ei creativitatea, transmisă sub formă de cod.

În timpul domniei lui Mihai Viteazul (1593-1601) orașul a fost implicat în sângeroase lupte duse cu Imperiul Otoman, pentru asigurarea pazei Dunării. În această perioadă, viteazul voievod a reorganizat armata, importante gamizoane de călăraşi fiind aşezate în câteva aşezări urbane, printre care şi Târgul de Floci ${ }^{22}$. În oraş trebuie să fi existat construcţii anume destinate căpitanii de

22 Maria-Venera Rädulescu, Cahlele medievale cu reprezentări de călăraşi descoperite la Oraşul de Floci Documente istorice, MN, XXII (sub tipar). 
călăraşi unde se puteau aduma pentru a stabilii strategia şi tactica luptelor.

Cele două locuinţe unde au fost descoperite instalaţiile de încălzit decorate deopotrivā atât cu leul bărbos păzind copacul vietii creștine, adăugăın noi, dar şi cu oşteni ecveştri, lăncieri sau stegari, presupunem că aveau acest caracter special, ele putând fi, în acelaşi timp, locuinţe private ale căpeteniilor de călăraşi dar şi cartiere generale, pe timp de luptă. Oştenii ecveştri redaţi pe cahlele ce compuneau sobele celor două locuinţe medievale înfăţişau, desigur, călăraşii prezenţi în oraş, călăraşii ce făceau parte din oastea lui Mihai Viteazul.

Motivul decorativ leul bărbos păzind copacul vietii ivit pe teracotele din Europa centrală în zorii secolului al XV-lea, călătorind spre Dunăre mai bine de un secol şi jumătate, primeşte, de astă dată, valenţe de simbol, cu rezonanţe locale.

Iconografia cahlelor medievale se înscrie ca document important în înţelegerea atât a aspectelor de viaţă cotidiană, cât şi a nivelului de cultură şi spiritualitate, a mentalităţii epocii.

\section{BIBLIOGRAFIE}

Batariuc 1995 -- P. V. Batariuc. Motive decorative de inspirafie literară pe cahle din secolele $X V-X V I, \mathrm{AT}, \mathrm{V}, 1995$. Batariuc 1999 - P. V. Batariuc, Cahlele din Moldova medievală. Secolele XIV-XVII, Suceava, 1999.

Chiţescu et alii 1981 - L. Chiţescu, R. Lungu, T. Papasima, P. Vlădilă, V. Rădulescu, A. Păunescu, Cercetăr $i$ arheologice in anul 1979 la Piua Petrii (Orassul de Floci), comuna Giurgeni, CercA, IV, Bucureşti, 1981, p. 120-143.

Chițescu et alii 1982 - L. Chițescu, T. Papasima, P. Vlădilă, V. Rădulescu, A. Păunescu, Cercetările arheologice de la Pinca Petrii (Oraşul de Floci), jud. Ialomita, CercA, V, 1982, p. 129-166.

Chiţescu, Teodor 1996 - L. Chiţescu, S. Teodor, Piua Petrii (Oraşul de Floci), com. Giurgeni, jud. lalomita Sectorul Grind l, CCA, 1996, p. 89, nr. 107.

Chițcscu, Teodor 1997 - L. Chiţescu, E. S. Teodor, Orassul de Floci, com. Giurgeni, jud. lalomita - Sector Grind l, CCA, 1997, p. 44-45, nr. 78.

Franz 1969 - R. Franz, Der Kachelofen. Entstehung und kunstgeschichtliche Entwicklung vom Mittelalter bis zum Ausgang des Klassizismus, Graz, 1969.

Holl 1958 - I. Holl, Középkori kályhacsempék Magyarországon I. Az udvari központok mühelyei és hatásuk a vidéki fazekassiggra (XIV. század-XV. század közepe), BudRég, XVIII, 1958, p. $211-300$.

Ilicscu, Puşcaşu 1970 - A. Iliescu, V. M. Puşcaşu, Plăci ceramice descoperite în cursul cercetărilor de la Cetatea Făgăras, BMI, anul XXXIX, 1970, nr. 4, p. 11-16.

Marcu-Istrate 2004 - D. Marcu-Istrate, Cahlele din Transilvania şi Banat de la inceputturi până la 1700, ClujNapoca, 2004.

Popa, Mărgincanu-Cârstoiu 1979 - R. Popa, M. Mărgineanu-Cârstoiu, Mărturii de civilizafie medievală românească. O casă a domniei si o sobă monumentală de la Suceava din vremea lui Şlefan cel Mare, București, 1979.

Puşcașu 1980 - V. M. Puşcaşu, Plăci ceramice decorative descoperite la Cetatea Făgăraşului in anii 1966-1973, Acta Moldaviac Meridionalis, II, 1980, p. 225-271.

Rădulescu 2000 - M. V. Rădulescu, Noi cahle medievale decorate cu scene de turnir (secolele XIV-XVI), SiCercistorV, 2000, nr. 1-2, p. 93-102.

Richterová 1982 - J. Richterová, Středovékě Kachle, Praga, 1982.

Tamási 1995 - J. Tamási, Verwandte Typen im Schweizerischen und Ungarischen Kachelfitndmaterial in der zweiten Hälfie des 15. Jahrhunderts. Vergleischsuntersuchungen zu den Werkstattbeziehungen zwischen dem Oberrheinischen Renum und Ungarn. Budapest, 1995.

Tcodor 1998 - E. S. Teodor, Oraşul de Floci, com. Ginrgeni, jud. Ialomita. Sector Grind I, CCA, 1998, p. 48-49, nr. 56.

Voit, Holl 1963 - P. Voit, I. Holl, Anciens carreaux de poêle hongrois, Budapest, 1963. 


\section{LISTA ILUSTRATIILOR}

Pl. 1. Cahle medievale descoperite la: 1. Cetatea de la Suceava, după Batariuc 1999); 2. Curtea Domnească de la Vaslui; 3. Colecţia Figdor, după Holl 1958); 4. Palatul Regal de la Buda, după Holl 1958 (a doua jumătate a secolului al XVlea).

Pl. 2. Cahle medievale descoperite la Cetatea Făgăraş 1. După Puşcaşu 1980; 2-3. După Marcu-Istrate 2004 (sfârşitul secolului al XV-lea - inceputul secolului al XVI-lea).

PI. 3. Cahlă medievală descoperită la Curtea Domnească din Târgovişte (sfârşitul secolului al XV-lea - începutul secolului al XVI-lea).

PI. 4. Cahle medievale descoperite la Oraşul de Floci: 1. Fragmente, locuinţa L/1978; 2. Locuinţa L5A/1995, plan Eugen S. Teodor (sfârşitul secolului al XVI-lea).

PI. 5. Oraşul de Floci: 1. Locuinţa medievală L5A/1995 (plan Eugen S. Teodor); 2. Cahlă medievală descoperită în L5A/1995 (sfầrşitul secolului al XVI-lea).

\section{LIST OF ILUSTRATIONS}

PI. 1. Medieval stove tiles: 1. Suceava Stronghold, after Batariuc 1999; 2. Vaslui Royal Court; 3. Figdor Collection, after Holl 1958; 4. Buda Royal Palace, after Holl 1958 (second half of the $X V^{\text {th }}$ century)

PI. 2. Medieval stove tiles found at Făgăraş Stronghold 1. Pușcaşu 1980, 2-3. Marcu-Istrate 2004 (the end of $X V^{\text {Ul }}$ century -- the beginning of the $\mathrm{XVI}^{\mathrm{U}}$ century).

PI. 3. Medieval stove tile found at Târgoviște Royal Court (the end of the $X V^{\text {th }}$ century - the beginning of the $X V I^{\text {th }}$ century).

Pl. 4. Medieval stove tiles found at Floci City: 1. fragments, L 1978; 2. The medieval dwelling L 5 A 1995, ground plan made by Eugen S. Teodor 1995 (the end of the XVI ${ }^{\text {ll }}$ century).

PI. 5. Floci City: 1. The medieval dwelling L 5 A 1995 (ground plan made by Silviu Teodor); 2. Medieval stove tile found in the dwelling L 5 A 1995 (the end of the $\mathrm{XVI}^{\text {th }}$ century).

TRADUCERE REZUMAT:

Maria Venera Rădulescu

\section{FOTO CAHLĀ:}

George Nica

Maria Venera Rădulescu

Muzeul Naţional de Istorie a României

Calea Victoriei 12, sector 3, 030026 ,

Bucureşti 

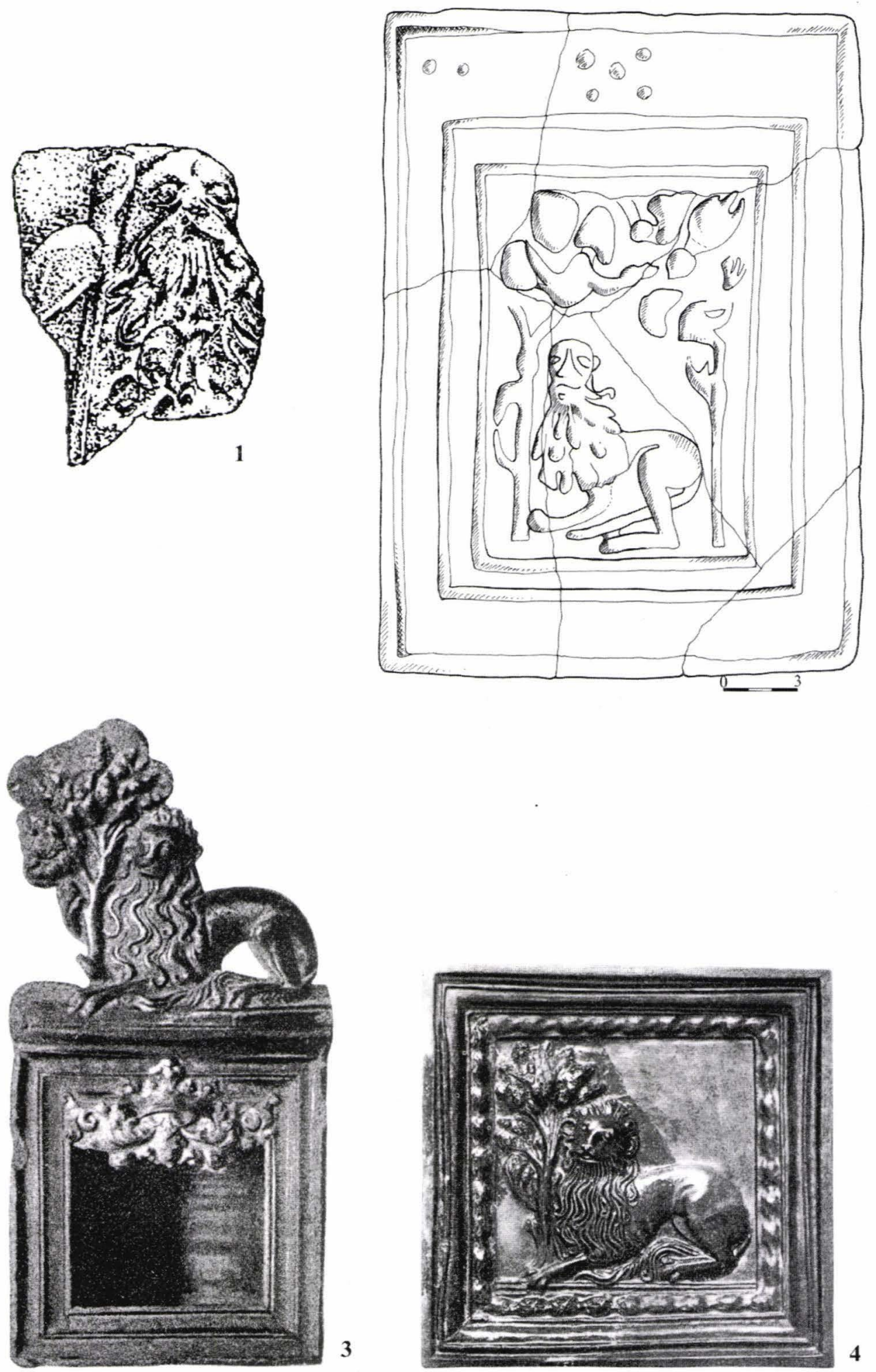

4

Pl. 1 - Cahle medievale descoperite la: 1. Cetatea de la Suceava, după Batariuc 1999;

2. Curtea Domnească de la Vaslui; 3. Colecţia Figdor, după Holl 1958;

4. Palatul regal de la Buda, după Holl 1958 (a doua jumătate a secolului al XV-lea). 

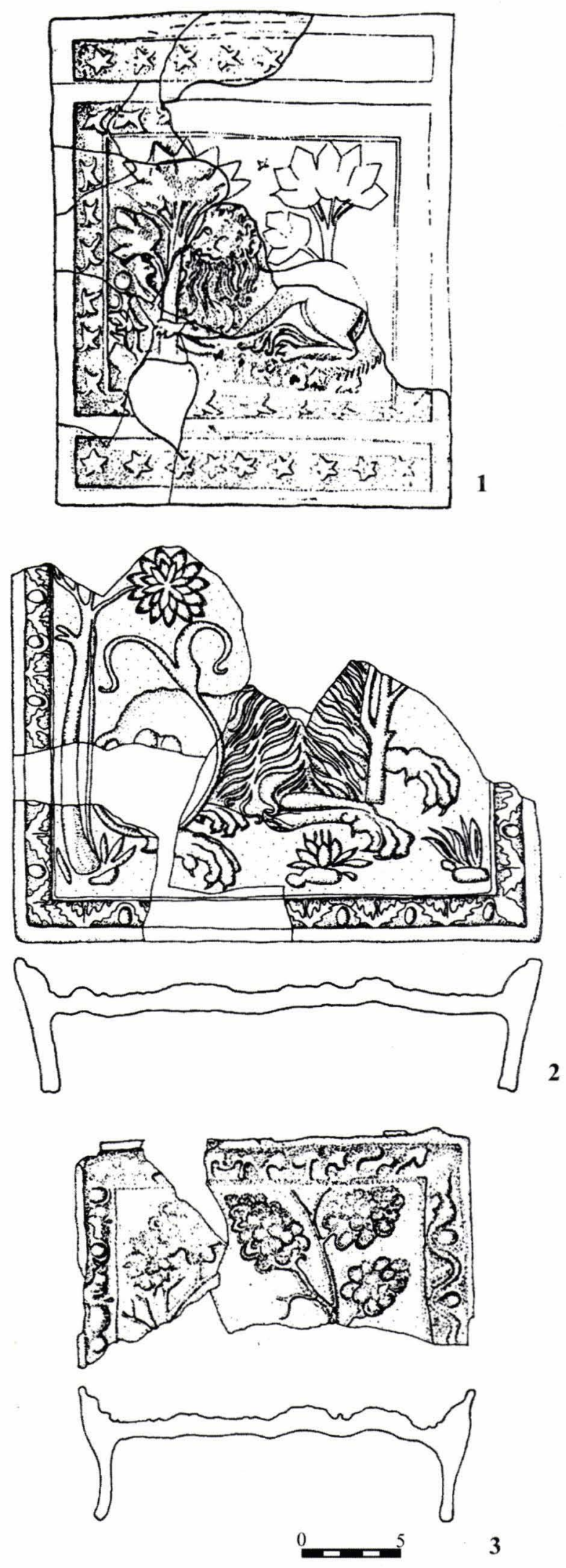

PI. 2 - Cahle medievale descoperite la Cetatea Făgăraş: 1. După Puşcaşu 1980; 2-3. După Marcu-Istrate 2004 (sfârrşitul secolului al XV-lea - începutul secolului al XVI-lea). 


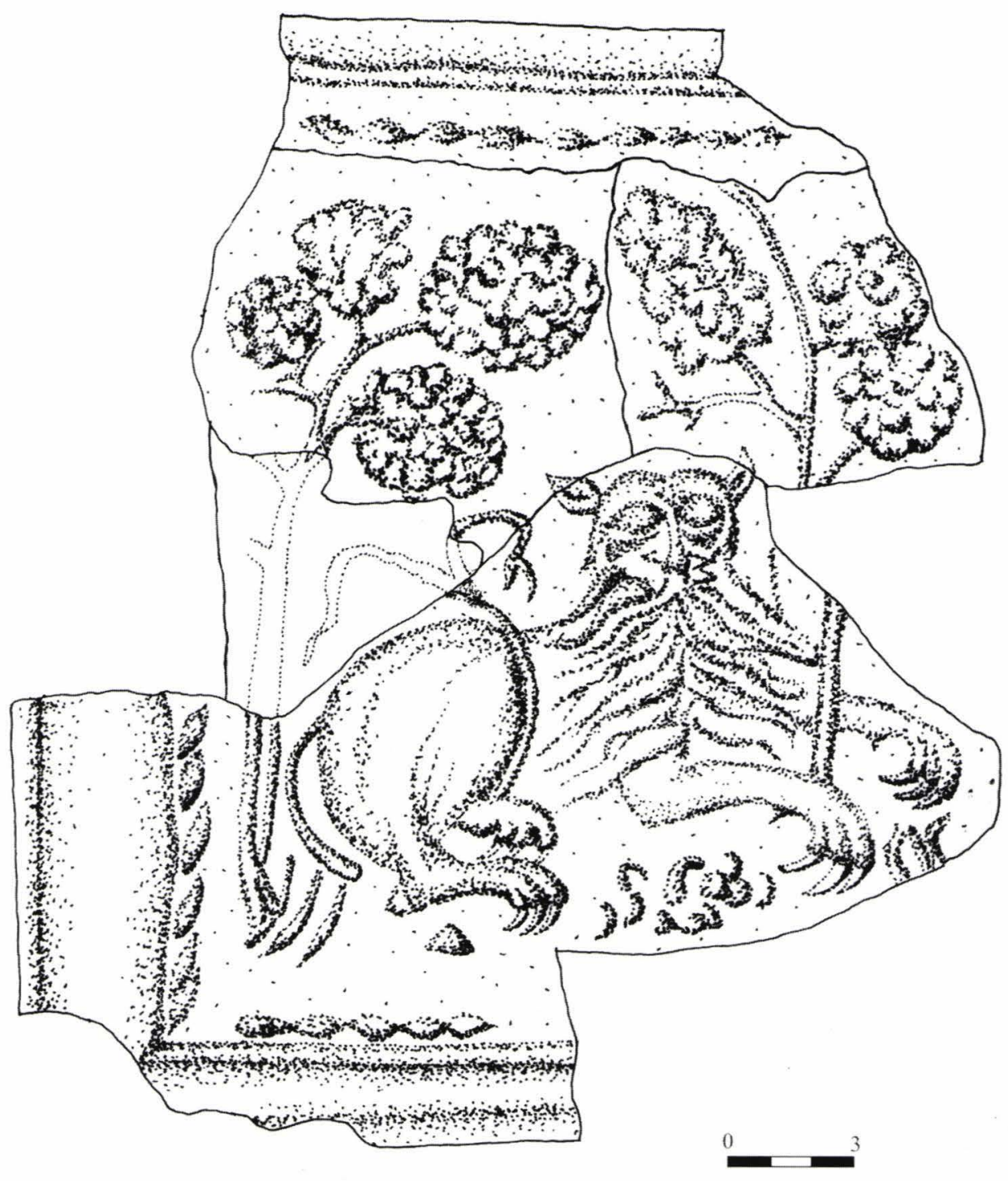

PI. 3 - Cahlă medievală descoperită la Curtea Domnească din Târgovişte (sfârşitul secolului al XV-lea - începutul secolului al XVI-lea) 

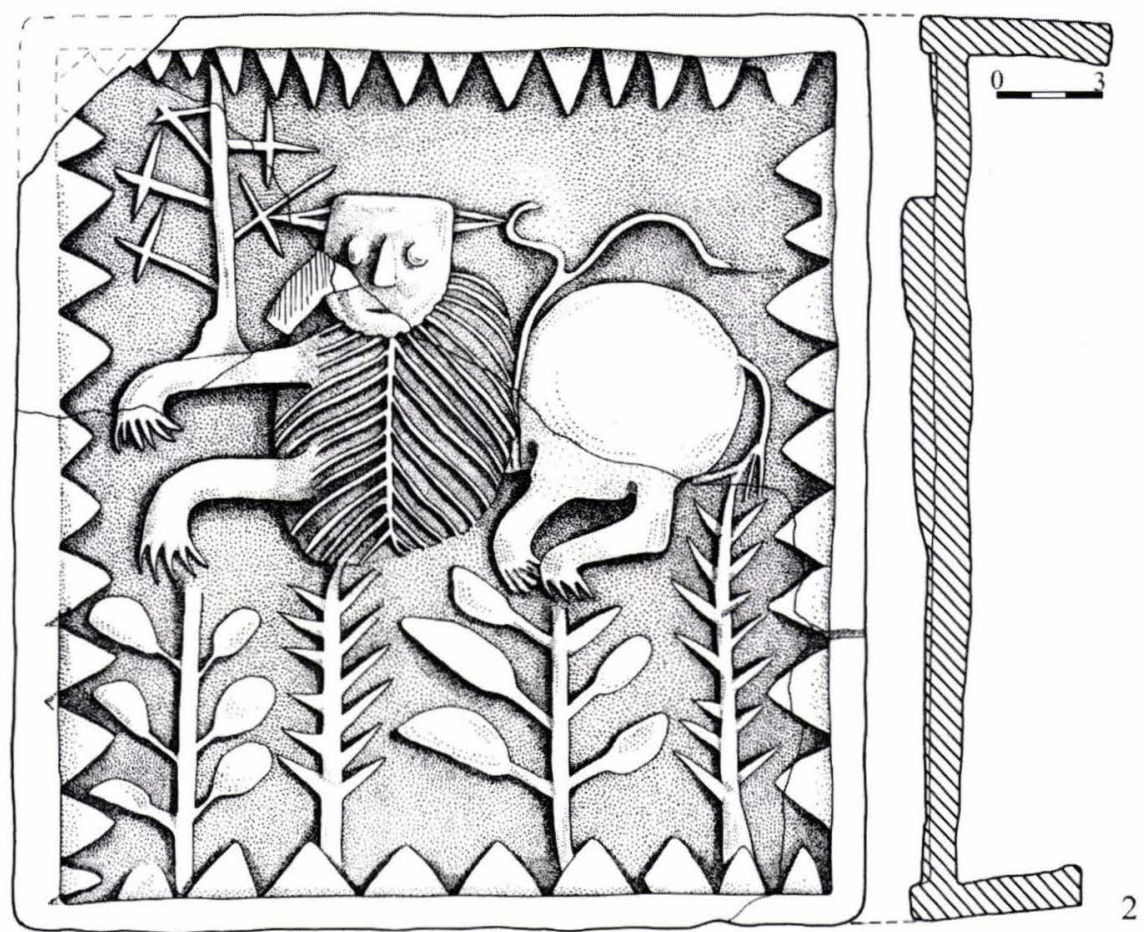

Pl. 4 - Cahle medievale descoperite la Oraşul de Floci: 1. Fragmente, Locuința L/1978; 2. Locuinţa L5A/1995 (sfârşitul secolului al XVI-lea) 


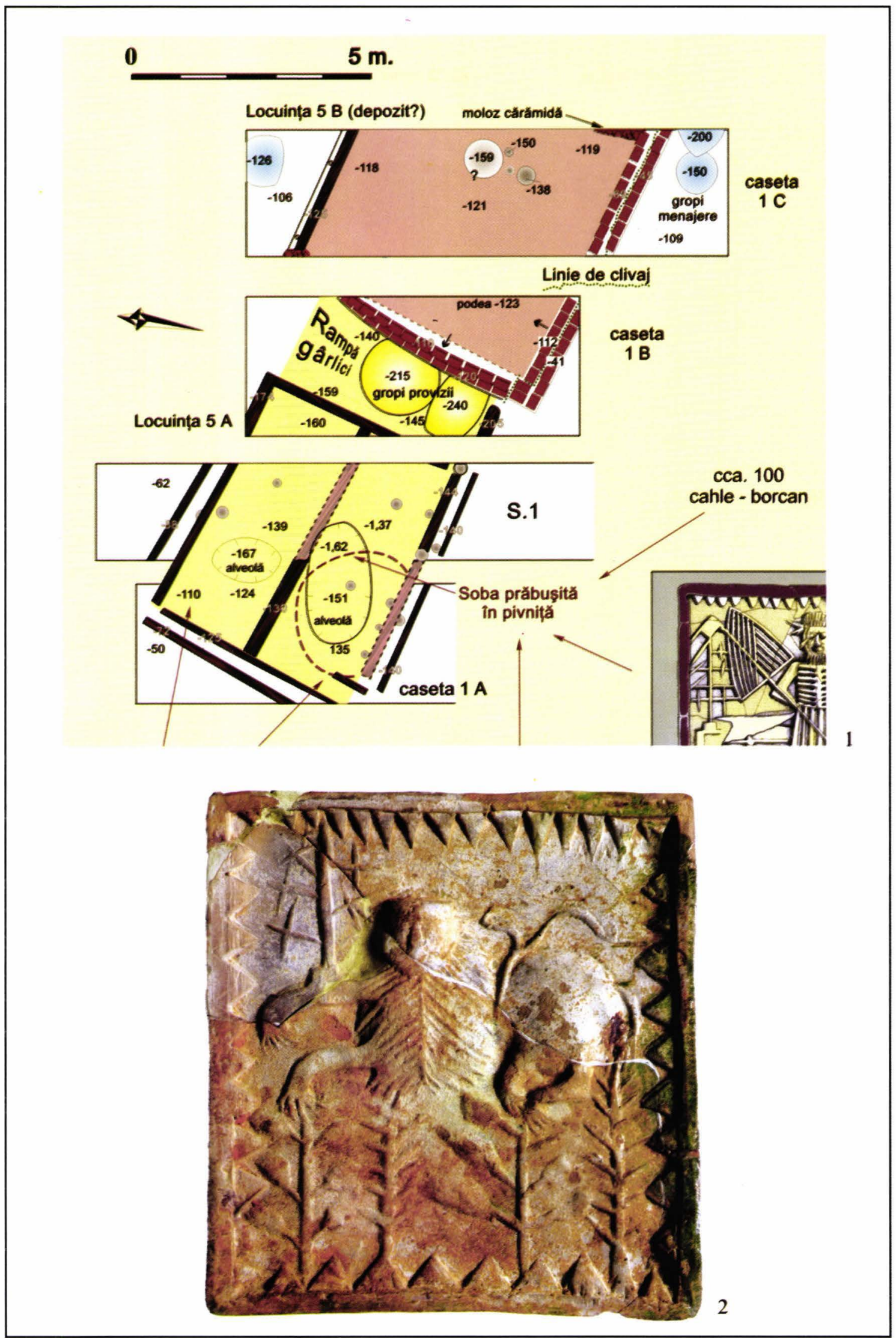

PI. 5 - Oraşul de Floci: 1. Locuinţa medievală L5A/1995 (plan Eugen S. Teodor);

2. Cahlă medievală descoperită în locuința L5A/1995 (sfârşitul secolului al XVI-lea) 
